\title{
VISITORS PERCEPTION ABOUT THE SAPTA PESONA IMPLEMENTATION IN KAMPUNG FLORY SLEMAN YOGYAKARTA
}

\author{
Achmad Septio, Tuti Karyani, Endah Djuwendah. \\ Universitas Padjadjaran, Indonesia. \\ achmadseptio27@gmail.com.
}

\begin{abstract}
Sapta pesona is a condition who expected to be able to create a comfortable and give a good impression to every visitor who comes. Kampung Flory is one of the agro-tourism located in Sleman Regency, Special Region of Yogyakarta, which began popular since 2016. The potential offered is quite diverse, ranging from nature tourism, outbound, to culinary with a distinctive nuance. Based on visitor's data from January to July 2019, there was a decrease from January to April 2019. This study aims to determine visitors' perceptions about the implementation of sapta pesona in Kampung Flory. The method used is qualitative with a case study. The results showed that the implementation of sapta pesona in Kampung Flory was good, but there were still some things that needed to be improved especially joglo souvenirs as aspects of the memory attribute.
\end{abstract}

Keywords : Perception, Sapta pesona, Agro-tourism, Kampung Flory

\section{INTRODUCTION}

Tourism can be said as one of the needs who every human being. Tourism activities can relax themselves, eliminate boredom, and increase creativity. Indonesia is a country with diverse natural resources and cultural arts heritage. One way that can be done in utilizing these resources is to manage and develop them into tourist objects and attractions. Tourism destinations owned by Indonesia consist of nature, culture and man-made (Haryanto, 2016)

Based on the 2016 Ministry of Tourism Pocket Book the tourism sector in 2014 was able to contribute up to $9 \%$ or around Rp 946.09 trillion to national GDP. Foreign exchange from the tourism sector in the same year reached Rp 120 trillion and contributed to employment opportunities of 11 million people (Anggraini dan Riyanto, 2017). Current tourism development leads to rural local empowerment as a model of sustainable tourism development in accordance with government policy in the field of tourism (Atmoko, 2014). The government issued 7 policies related to tourism strategies, one of which is by applying the sapta pesona program as a condition that must be realized in every object and tourist attraction in Indonesia (Rahmawati et al, 2017).

Firmansyah (2012) revealed that sapta pesona is a description of the concept tourism awareness that concerns the support and participation of the community in creating a conducive atmosphere and environment so as to encourage the growth and development of tourism including the realization aspects of safety, orderly, cleanliness, beauty, coolness, friendliness and the memories. Thus it is expected 
that the tourism sector in Indonesia can continue to increase the number of tourists, both domestic and foreign, so that it will positively influence foreign exchange earnings.

October 2018, WTTC (World Travel and Tourism Council) announced that Indonesia was ranked ninth in the world as the fastest growing tourism country (Kementerian Pariwisata, 2019). Indonesia and Malaysia are also ranked first as the object and destination of halal world tourism by GMTI (Global Muslim Travel Index). These achievements become opportunities and challenges for the government and other elements in developing Indonesian tourism.

The concept of back to nature is becoming the current trend of tourism development. The concept is very suitable with the condition of Indonesia which has diverse and abundant natural resources. Tourism that has the potential to be developed with the concept of back to nature is agro-tourism which is a rural development concept that makes agricultural activities and natural atmosphere as a tourist attraction and prioritizes aspects of community life, the preservation of natural resources and the environment. The concept of agro-tourism can be an opportunity for local farmers to increase the amount of income, provide opportunities and employment opportunities for the community, as well as protect natural and biological wealth (Muchlis dan Eko, 2017)

Special Region of Yogyakarta is one of the provinces in Indonesia which has a high tourist attractiveness both by domestic and foreign tourists. Some of the factors that become an attraction include culture and history, community friendliness, good climate, diverse scenery, and relatively cheap prices. This is in accordance with the Regional Regulation of the Special Region of Yogyakarta No. 1 of 2012 concerning the Master Plan for the Development of Tourism in the Special Region of Yogyakarta in 2012-2025 which states that tourism development is directed in accordance with the vision of the regional government, namely to make the Special Region of Yogyakarta as a leading cultural-based tourist destination in Southeast Asia, world class, competitive, sustainable and able to encourage regional development for the welfare of the people.

Table 1. Number of Tourist Visits in Tourism Attractions by Regency/City in 2017.

\begin{tabular}{llll}
\hline Regency/City & $\begin{array}{l}\text { Domestic } \\
\text { Tourist (people) }\end{array}$ & $\begin{array}{l}\text { Foreign } \\
\text { Tourist } \\
\text { (people) }\end{array}$ & $\begin{array}{l}\text { Total } \\
\text { (people) }\end{array}$ \\
\hline Yogyakarta & 298.018 & 5.049 .608 & 5.347 .626 \\
\hline Sleman & $\mathbf{2 5 0 . 4 1 8}$ & $\mathbf{6 . 5 6 4 . 1 4 0}$ & $\mathbf{6 . 8 1 4 . 5 5 8}$ \\
\hline Bantul & 10.493 & 9.130 .657 & 9.141 .150 \\
\hline Kulon Progo & 10.455 & 1.390 .331 & 1.400 .786 \\
\hline Gunung Kidul & 21.067 & 3.225 .929 & 3.246 .996 \\
\hline
\end{tabular}

Source : Dinas Pariwisata DIY, 2018

Table 1 shows the distribution of the number of tourists in the Special Region of Yogyakarta in 2017. Bantul Regency is the region that is most in demand by domestic tourists and the city of Yogyakarta is most in demand by foreign tourists. However, Sleman Regency is ranked as the second most popular tourist destination by both foreign and domestic tourists. This is certainly an opportunity for local governments to continue to develop their tourism potential. 
Sleman Regency has various tourism potentials which are more diverse compared to other regencies or cities in Special Region of Yogyakarta (Table 2). One of the tourism potentials is Kampung Flory, located in Tridadi Village, Sleman District, Sleman Regency, Special Region of Yogyakarta.

Table 2. Potential Attractions in Special Region of Yogyakarta in 2017. Type of Attraction (Object)

\begin{tabular}{lcccc}
\cline { 2 - 4 } Regency/City & Culture & Museum & $\begin{array}{c}\text { Nature and } \\
\text { other } \\
\text { attractions }\end{array}$ & $\begin{array}{c}\text { Total } \\
\text { (object) }\end{array}$ \\
\hline Yogyakarta & 5 & 14 & 6 & 25 \\
\hline Sleman & $\mathbf{9}$ & $\mathbf{1 0}$ & $\mathbf{2 7}$ & $\mathbf{4 6}$ \\
\hline Bantul & - & 7 & 46 & 53 \\
\hline Kulon Progo & - & - & 16 & 16 \\
\hline Gunung Kidul & - & - & 10 & 10 \\
\hline
\end{tabular}

Source : Dinas Pariwisata DIY, 2018.

Kampung Flory is began popular since 2016. Geographically, Kampung Flory is located between two villages, namely tridadi village and tlogoadi village. Not only presenting agriculture, agro-tourism also provides outbound and culinary areas that involve cultural elements and local wisdom. The visitors can enjoy the beauty of the agricultural area consisting of agro fruit and ornamental plants and can immediately try the practice of cultivation and buy existing seeds. In addition, visitors can try the outbound arena and traditional toys as well as rural cuisine.

As a tourist area, the adoption concept of sapta pesona is important in the development because it can encourage the awareness of many residents to be a good host. After that, the continuation of the sapta pesona is able to attract a number of tourists visiting the region so that it will have a positive impact on the socioeconomic conditions of the community. Based on observations that were carried out, even though Kampung Flory was included in the nomination of Anugerah Pesona Indonesia in 2019, it appeared that there were only a few parties who favored the concept of sapta pesona such as the head of Kampung Flory. The potential result will affect the success of the visitors who can make decisions on a number of visits.

\section{METHODOLOGY}

This study uses a qualitative design with a case study approach, which is to find out visitors' perceptions about the sapta pesona implementation in Kampung Flory. Data collection techniques obtained through observation and interviews with the selection of informants by accidental and quota sampling means that the informant was chosen because it is located in the Kampung Flory area and is willing to be interviewed. The number of visitors used as informants is 50 visitors.

There are two analytical methods used in this research. The first thing to do is to analyze qualitatively according to Miles and Huberman (in Satori and Komariah, 2017) in the form of reductions, servicing, and conclusions. Then the 
second analysis will be quantitative by analyzing descriptive statistics. This research uses a credibility test with triangles of sources as a test of reliability.

\section{General Overview of Kampung Flory}

\section{RESULT AND DISCUSSION}

Kampung Flory is administratively located in Jugang Pangukan Hamlet, Tridadi Village, Sleman District, Sleman Regency, Special Region of Yogyakarta. However, geographically the Taruna Tani Flory zone is located in Jugang Pangukan Hamlet, Tridadi Village, Sleman District while the Flory Tourism Village and Bali nDeso Group zones are located in Plaosan Hamlet, Tlogoadi Village, Mlati District, Yogyakarta Special Region. The boundaries of Kampung Flory are:

$\begin{array}{lll}\text { - } & \text { North side } & \text { : Tridadi Village } \\ \text { - } & \text { South side } & \text { : Tlogoadi Village } \\ \text { - } & \text { West side } & \text { : Puri Mataram, Tridadi Village } \\ & \text { : Tlogoadi Village }\end{array}$

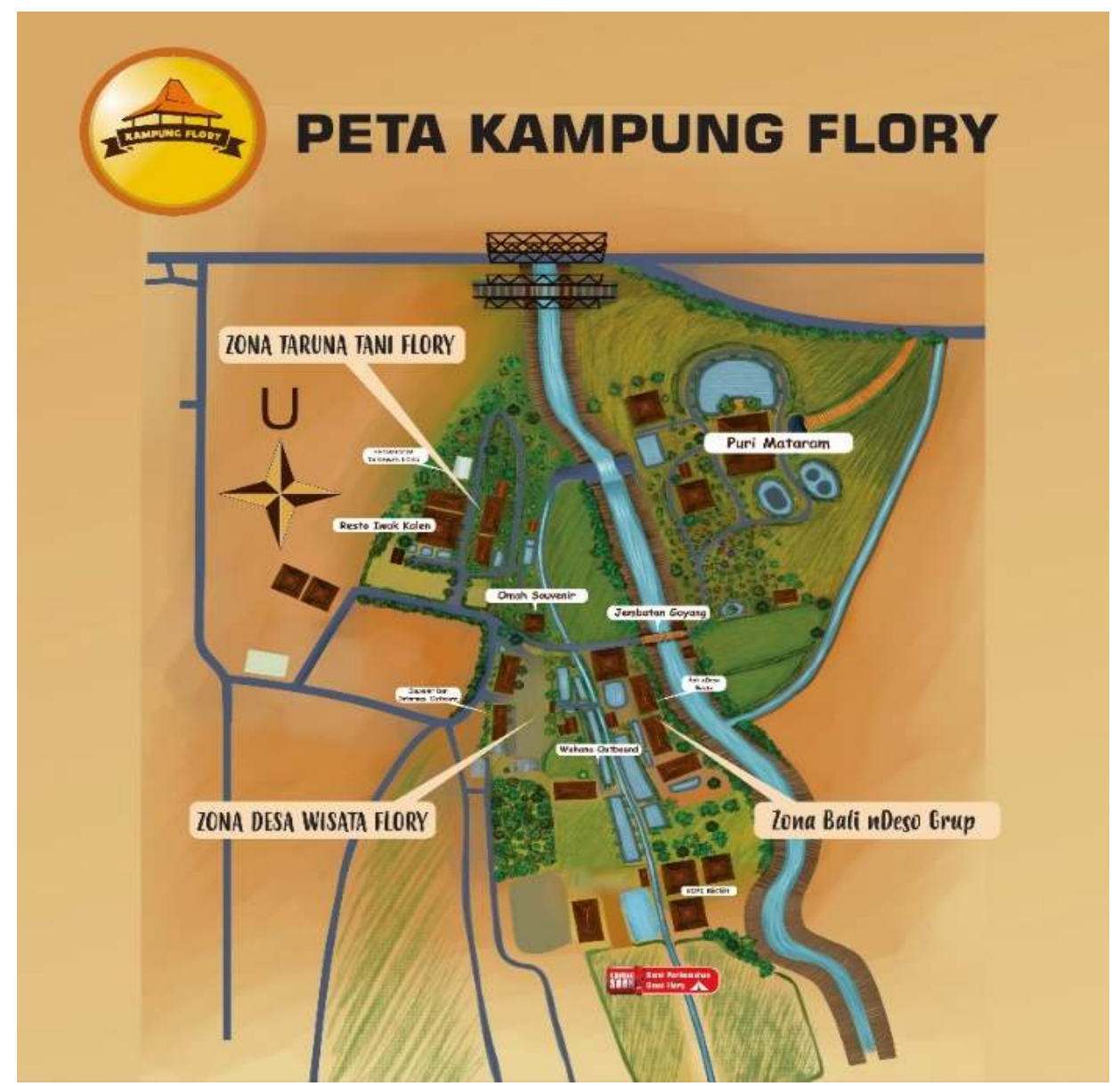

Figure 1. Location Map of Kampung Flory Source : Management of Kampung Flory (2019) 
The area of Kampung Flory consists of three zones, namely the Taruna Tani Flory zone which is on the land owned by the treasury of Tridadi Village with an area of approximately $8,700 \mathrm{~m}^{2}$. The second is the Flory Tourism Village zone which is on the land owned by the Tlogoadi Village treasury with an area of approximately 14,000 $\mathrm{m}^{2}$. Finally, the Bali nDeso Group zone which stands on privately owned and community-owned land covering an area of approximately $6,000 \mathrm{~m}^{2}$ that engages with the Kampung Flory.

\section{Facilities of Kampung Flory}

The facilities available at Kampung Flory (Table 3) are quite complete and in good condition, only ATM center facilities are not provided because Kampung Flory wants to keep traditional and rural nuances.

Table 3. The facilities in Kampung Flory

\begin{tabular}{llc}
\hline Nu. & Facilities & Total (object) \\
\hline 1. & Information Center & 1 \\
\hline 2. & Homestay & 2 \\
\hline 3. & Restaurants & 3 \\
\hline 4. & Souvenir Place & 1 \\
\hline 5. & Musholla & 2 \\
\hline 6. & Toilet & 15 \\
\hline 7. & Parking Area & 3 \\
\hline 8. & Security Post & 2 \\
\hline 9. & Healthy Post & 1 \\
\hline 10. & Saung or Limasan & 4 \\
\hline
\end{tabular}

One of the facilities that must be in a tourist area is a toilet. For toilet facilities, the management provides approximately fifteen toilets with different conditions, there are conditions that are very good and some are still not good even have not been completed but have been used because of the needs of visitors. The manager also provides two toilets for disabilities.

Other supporting facilities are Bali nDeso Restaurants and Iwak Kalen for culinary tours for visitors and joglo souvenirs that provide souvenirs typical of Kampung Flory made directly by the community around the area. Joglo souvenirs were built with funding from Bank Indonesia's CSR, but the management has not been maximized. The typical building shape of a nice and spacious jogja house is very unfortunate because it only consists of a number of souvenirs. The arrangement and cleanliness of goods and places can also be said to be still not good so it is less attractive for visitors to buy. 

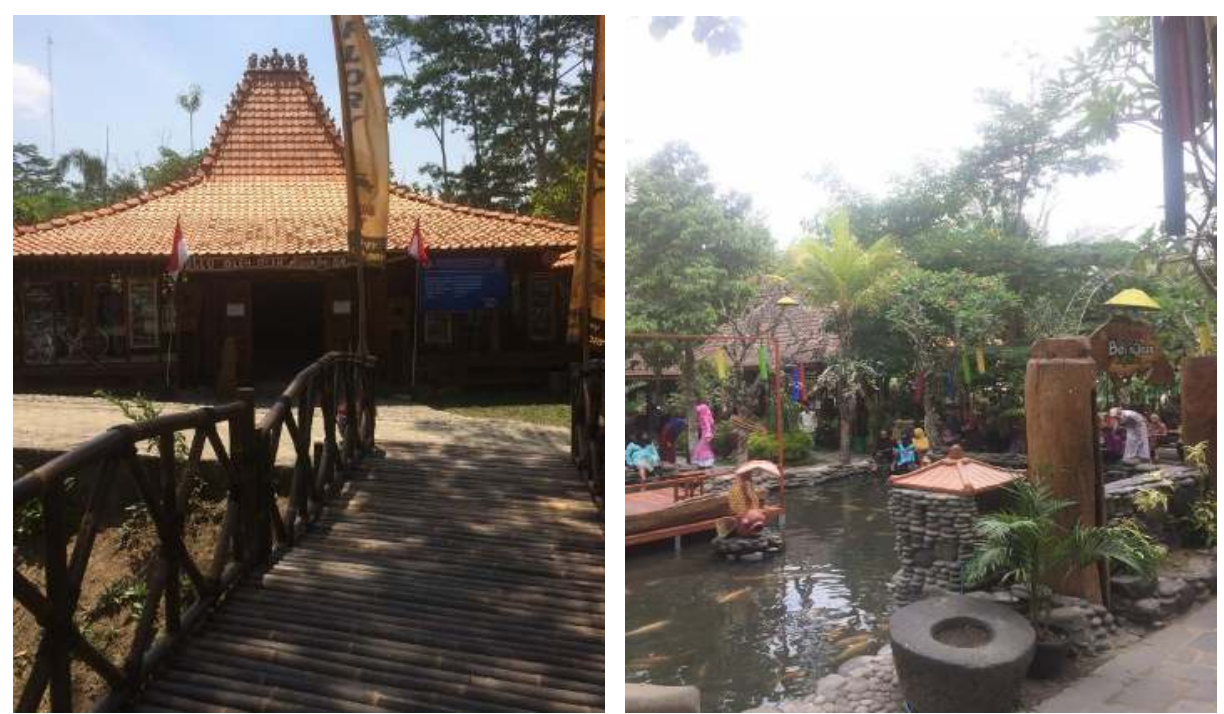

Figure 2. Joglo Souvenirs and Bali nDeso Restaurant

Sources : Personal Documentation (2019)

\section{Accessibility of Kampung Flory}

Kampung Flory is quite strategic and easily accessible. In accordance with the results of Saputra and Tuti's research (2015) that the motivation of consumers decides to visit an area for reasons of easily accessible. Located near the integrated district government center of Sleman Regency, Kampung Flory can be reached in less than 6 minutes with a distance of $2.5 \mathrm{~km}$ using a motor vehicle or car from the Sleman Regency Square. From the center of Yogyakarta City, Kampung Flory also has fairly easy access because the road does not turn or climb with a distance of approximately $12 \mathrm{~km}$ with a time of 23 minutes, namely through Jalan Magelang and then past the Jombor bridge still straight north to meet the red light crossing Denggung Sleman, then turn left past the Sleman Regency government office complex to meet the Pangukan bridge. From the bridge is a little straight on the left side of the road there are directions to the tourist sites of Kampung Flory. The condition of the road which is paved and in good condition makes it very easy for visitors to Kampung Flory. Kampung Flory is really inside a village, so if visitors want to come to Kampung Flory it will pass the village houses first. The village road that is not too big is only enough for cars, motorbikes and medium-sized buses to get into the area of Kampung Flory. For large buses, parking lots are located approximately $200 \mathrm{~m}$ outside the Kampung Flory area. For pedestrians, it can be through a shortcut that is entering the Puri Mataram area which will later be connected to Kampung Flory via a rocking bridge.

\section{Implementation of Sapta Pesona Safety}

As a tourist area, Kampung Flory takes several actions to provide a sense of security to visitors, including the presence of security posts, parking area equipped with guards, periodic checking of existing facilities and not disturbing tourists while in the area. This is in line with the research conducted by Amirullah (2016) that not 
disturbing tourists can be a factor that influences the reality and comfort of tourists in visiting.

To minimize accidents when traveling in this case is outbound, at least the manager must take the following three steps namely by targeting tourists who will enjoy the attraction, the acquisition of knowledge and ability to communicate, and carry out maintenance of the facilities. Manager of Kampung Flory has tried to implement this step and based on the results of interviews with managers, so far there have been no visitors who gave reports related to the loss of goods, criminal acts, or accidents that occurred in Kampung Flory area.

\section{Orderliness}

To realize orderliness, Kampung Flory does several ways, namely providing a special parking area for motorbikes, cars, and buses. The manager also provides a map of Kampung Flory to facilitate visitors in carrying out tourist activities in Kampung Flory. In addition, the manager tries to obey the rules that apply to the local community and provide advice and direction to visitors while in the Kampung Flory area.

Firmansyah (2012) states that orderliness is a condition of creating an orderly, neat, and smooth condition in tourist areas. According to interviews with the management, Kampung Flory has provided a separate place for traders. The problem that still often occurs is the parking position, sometimes car or motorcycle users park their vehicles directly without following the directions of the parking guard. This was also conveyed by a number of visitors interviewed, but so far the aspect of orderliness in Kampung Flory was considered quite good. The location arrangement is neat making it easier for visitors to travel.

\section{Cleanliness}

Cleanliness is an important aspect in a tourist area. Kampung Flory in creating an atmosphere of cleanliness is to provide trash bins in several places. When there is a tour group, the manager also provides a special trash bin to make it easier. According to Khalik (2014) the environment of the tourist area must be maintained by not littering and maintaining the cleanliness of public facilities so as not to damage existing ecosystems, cause disease and not affect the comfort of visitors.

Not only that, the manager also strives to cleanliness for toilet facilities and prayer rooms every day so that visitors are comfortable in using it. The manager provides around fifteen toilets and also provides two special toilets for the disabled. The manager also gave an appeal in the form of writing so that visitors help in maintaining the cleanliness of the environment, especially toilets and prayer rooms.

Based on the results of interviews with visitors, the condition of Kampung Flory was clean enough. The manager has also provided a closed landfill so that it does not cause odors for visitors. Trash bins provided are still not enough, so there are still some visitors who litter. Toilets and prayer rooms have so far been classified as clean and neat so as to provide comfort for visitors in using them.

\section{Beauty}

The beauty of Kampung Flory is a gift from the God which is then managed by the community. The existence of a rocking bridge that has a funny design and is 
above the clear Bedog river very spoil the eyes of visitors. The area of taruna tani flory agrotourism that contains various types of ornamental plants also provides its own beauty for visitors.

Hakim (2014) explains that human nature will always need the beauty of biodiversity harmonization for pleasure and peace of mind. In the opinion of visitors, Kampung Flory is an urban tourist attraction that offers a natural and beautiful rural feel. Various types of ornamental plants provided are very pampering visitors. Every corner of Kampung Flory always gives its own beauty both from the shape of the building, the decoration of the walls, and the arrangement of tourist objects.

\section{Coolness}

Kampung Flory is located in an urban area, precisely close to the center of Sleman Regency government. The weather was quite hot, but the manager tried to provide coolness by the arrangement of various trees around the area, colorful ornamental plants, and various huts or shelter or rest.

Based on information from visitors, the restaurants is also nuanced of Java surrounded by various plants and fish ponds that provide coolness for visitors while waiting for orders. The sound of the Bedog river flow also gives visitors a cool and calm feeling. This is in accordance with what was conveyed by Firmansyah (2012) which states that the cool conditions can provide comfort for visitors.

\section{Friendliness}

Friendly attitude comes from the attitude of the people around the area who are trying to provide an atmosphere of openness to welcome visitors openly. This attitude is then complemented by direct training and education. The absence of written regulations for visitors makes the manager and the community provide information verbally. Friendly nature both in providing information, giving smiles and sincere hospitality to visitors needs to be improved (Amirullah, 2016) in order to create a comfortable atmosphere.

Some visitors argued that the manager of Kampung Flory was friendly in serving visitors, always trying to provide good and accurate information, giving a smile and trying to help visitors when needed. Communities around the area also try to show friendliness to every visitor who comes.

\section{Memories}

Memories will give a sense of pleasure and imprint in visitors. The application of the memory attributes in the management of Kampung Flory is not yet optimal. The manager provides souvenirs that provide a variety of souvenirs from the Kampung Flory made directly by the community. But in reality not too captivating visitors.

Based on the results of interviews with visitors, it was found that the indicator of memories had not yet made an impression on their hearts. Arrangement of goods, diversity and cleanliness of the product and the room are felt to be still lacking even though the space provided is large. Yet according to Yoeti (2008) here are three main characteristics of attractions that must be considered in the development of tourism products, namely (1) "Something to see" means that attractions must have a tourist product that can be seen or used as a spectacle for 
tourists. (2) "Something to do" means that a tourist attraction must have certain tourism products, for example in the form of recreational facilities, either play areas or eating places so that there are activities that tourists can do. And (3) "Something to buy" means that attractions must provide tourist products in the form of facilities for tourists to shop, such as souvenirs and handicrafts of people around the area.

Visitors Perception about the Sapta Pesona Implementation in Kampung Flory Based on the results of the statistical calculations carried out by taking the following numbers of items per indicator of the questions asked to the 50 informants obtained.

Table 4. Summary of Average Values of Sapta Pesona Implementation.

\begin{tabular}{|c|c|c|c|}
\hline $\mathrm{Nu}$ & Attribute & $\begin{array}{c}\text { Average } \\
\text { Value }\end{array}$ & Category \\
\hline 1 & Safety & 3,80 & Good \\
\hline 2 & Orderliness & 3,90 & Good \\
\hline 3 & Cleanliness & 3,91 & Good \\
\hline 4 & Coolness & 4,39 & Very Good \\
\hline 5 & Beauty & 4,45 & Very Good \\
\hline 6 & Friendliness & 3,84 & Good \\
\hline 7 & Memories & 3,30 & Quite Good \\
\hline Tota & I Average Value & 3,94 & Good \\
\hline
\end{tabular}

Based on Table 4, it can be seen that overall the application of sapta pesona carried out by Kampung Flory in Sleman Yogyakarta based on the perception of visitors has a value of 3.94 and is classified as good. The two attributes that are the highest attraction in the eyes of visitors are coolness and beauty with each having an average value of 4.39 and 4.45. The figure shows two attributes that have been implemented very well by Kampung Flory Sleman Yogyakarta in entertaining visitors.

This is in line with the expectations of managers who want to make the area of Kampung Flory as a city tourist destination that provides a coolness and beauty atmosphere so that it can provide comfort for visitors. The coolness and beauty attributes are also a feature of Kampung Flory because the manager realizes that the majority of people or tourists want to travel for the purpose of wanting to take a vacation or relax, so Kampung Flory is very appropriate as a tourist destination.

The results of interviews with 50 informants also revealed that the majority of informants who came to Kampung Flory were the first or second visit. Visitors who come to get information about the Kampung Flory from people around him, even some do not know that the Kampung Flory has social media. Easy access and cool atmosphere is one reason to visit Kampung Flory. Some visitors also expect that in the future Kampung Flory will be equipped with an ATM machine to facilitate transactions while in the area. However, it has already been explained that the manager wants to maintain the traditional nuances in the tourist area.

Based on the statement of safety attributes, the majority of the informants agreed that access to Kampung Flory was easy, although it could not yet be passed by large buses. The division of zones in Kampung Floru is also very clear and neatly 
arranged so that it makes the visitors orderly and comfortable in the area. Clean food with a rustic feel is the main attraction for visitors.

In the memory attribute, the assessment of visitor informants on souvenirs or souvenirs is still low. This is caused by the lack of products or souvenirs offered at Joglo Souvenirs, while the space provided is quite large. The lack of active promotion of shopkeepers and the lack of order in arranging places is also one of the reasons visitors are not interested in buying souvenirs.

The existence of competitors that began to emerge, did not make Kampung Flory become empty of visitors. Outbound rides that are distinctively different from similar tourist objects make Kampung Flory still crowded with visitors dominated by school children from various regions around Yogyakarta. Efforts continue to be made by the manager to increase the number of visitors one of which is to provide a vehicle for the campsite which is currently in the finishing stage and will soon be opened in 2020.

Kampung Flory Manager continues to strive to provide the best for visitors one of them by always being friendly towards the visitors. In addition, the manager also tries to accept and correct any criticisms and suggestions given by visitors.

\section{CONCLUSION AND SUGGESTION}

\section{CONCLUSION}

Based on observations and interviews that were carried out to 50 visitor informants, it was concluded that sapta pesona implementation in Kampung Flory was not yet optimally acceptable. Coolness and beauty attributes become the priority of visitors choosing Kampung Flory as a tourist destination. The attribute of memories with a focus on joglo souvenirs is still a weakness of Kampung Flory because it has not been able to provide and promote souvenirs neatly and optimally.

\section{SUGGESTION}

Based on these conclusions, there are several suggestions that can be done, namely:

1. For the central government, it is expected to continually renew tourist assistance standards who included the explanation of the seven elements of sapta pesona remembering this time may even be a lot of tourism destination that is managed by the community.

2. For local governments, it is necessary to conduct regular observations of attractions that have been formed so that it something happens related to the sapta pesona can be finished immediately.

3. For managers, it is expected that there will be a lot of sapta pesona that has been done too. In this case, it is rearranging several places in Kampung Flory to make it look neat and attract attention especially the arrangement of parking lots and joglo souvenirs.

\section{ACKNOWLEDGMENT}

Thank you to the manager and visitors of Kampung Flory who are willing to be informants in this study. Thank you also to other parties who are willing to help both directly and indirectly in the research process. 


\section{REFERENCE}

Amirullah. 2016. "Penerapan Sapta pesona di Pantai Polewali Kabupaten Poliwali Mandar Provinsi Sulawesi Barat". Jurnal Kepariwisataan. Vol. 10 No. 2

Anggraini, Dewitri, dan Riyanto. 2017. "Analisis Hubungan Komplementer Dan Kompetisi Antar Destinasi Pariwisata (Studi Kasus: 10 Destinasi Pariwisata Prioritas Di Indonesia)". Jurnal Kebijakan Ekonomi, Vol 12, No.2.

Atmoko, T. Prasetyo Hadi. 2014. "Strategi Pengembangan Potensi Desa Wisata Brajan Kabupaten Sleman”. Jurnal Media Wisata, Vol. 12, No. 2

Dinas Pariwisata DIY. 2018. "Statistika Kepariwisataan Daerah Istimewa Yogyakarta 2017”. Sumber : https://visitingjogja.com/15691/statistikpariwisata-diy-2017/

Firmansyah. 2012. Pedoman Kelompok Sadar Wisata Direktorat Jendral Pengembangan Destinasi Pariwisata. Jakarta : Kementrian Pariwisata dan Ekonomi Kreatif

Hakim, Luchman. 2014. Enobotani dan Manajemen Kebun-Pekarangan Rumah: Ketahanan Pangan, Kesehatan, dan Agrowisata. Malang: Selaras

Kementerian Pariwisata. 2019. "Laporan Kinerja Kementerian Pariwisata 2018". Sumber: $\quad$ http://www.kemenpar.go.id/post/laporan-akuntabilitaskementerian-pariwisata-lakip-tahun-2018/

Khalik, Wahyu. 2014. "Kajian Kenyamanan dan Keamanan Wisatawan di Kawasan Pariwisata Kuta Lombok". JUMPA. Vol.1 No.1 halaman 23-42

Muchlis, Suryadi dan Eko Budi Santoso. 2017. "Penentuan Kriteria Pengembangan Agrowisata di Kecamatan Sukapura Kabupaten Probolinggo". Jurnal Teknik ITS. Vol. 6, No. 2

Peraturan Daerah Provinsi Daerah Keistimewaan Yogyakarta Nomor 1 Tahun 2012 tentang Rencana Induk Pembangunan Kepariwisataan Daerah Provinsi Daerah Istimewa Yogyakarta tahun 2012-2025. Sumber : https://www.bphn.go.id/data/documents/perda1-2012.pdf

Rahmawati, Siska Wahyu, Sunarti, dan Lukman Hakim. 2017. "Penerapan Sapta pesona Pada Desa Wisata (Analisis Persepsi Wisatawan atas Layanan Penyedia Jasa di Kampung Wisata Kungkuk, Desa Punten, Kota Batu)". Jurnal Administrasi Bisnis. Vol 50, No. 2

Saputra, Efrizal, dan Tuti Karyani. 2015. "Analisis Keputusan Berkunjung Serta Kepuasan Konsumen Agrowisata Cilangkap". Prosiding Seminar Nasional Pembangunan Inklusif di Sektor Pertanian II. Sumedang: 9 September 2015.

Satori, D, dan Komariah, A. 2017. Metodologi Penelitian Kualitatif. Bandung: Alfabeta

Yoeti OA. 2008. Ekonomi Pariwisata Introduksi, Informasi, dan Implementasi. Jakarta: Kompas Media Nusantara. 